\title{
A GENERAL SYSTEM OF COMPETENCIES THAT IS IMPORTANT FOR MODERN PEDAGOGICAL PROFESSIONALS
}

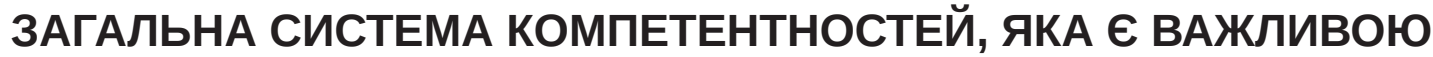 ДЛЯ СУЧАСНИХ ПЕДАГОГІЧНИХ ПРАЦІВНИКІВ}

Recent years, the professionalism and competence of teachers is often brought up. Concentration of professionalism and competence in a teacher is noted as the main features of his/her pedagogical skills and teacher innovation. This problem, which occupies one of the main places in education policy, is one of the issues of teacher training and teacher's professional activity. The education of these qualities is one of the first and foremost factors in ensuring the effectiveness, personality-oriented and result-oriented pedagogical activity. The professionalism and competence of a teacher makes the teaching profession more prestigious, more interesting, more meaningful and more effective. It is no secret that the low professionalism and low level of competence of some teachers play a significant role in the decline of the teaching profession and the reputation of teachers. The professionalism and competence of a teacher should help students to study better, gain deeper and more comprehensive knowledge, skills and habits in the educational process, master moral values, be formed as competitive professionals, be educated as worthy members of society. There is a great demand for competent and professional teachers in education, teachers who master new technologies, use them successfully in teaching, apply innovations in their activities, are attached to school, their profession, consider teaching as their life credo, literally breathe with it. Therefore, the study of this topic is relevant. While writing the article, the sources, internet resources and legislative documents written in the relevant field were analyzed. Improving the professional and professional training of teachers, their interest in innovation, constantly increasing their professional and professional knowledge, skills and habits, self-education, self-education and pedagogical creativity are the basis of his formation as a professional and competent teacher. Competence combines important aspects of personality. Competences are formed on the basis of skills. Many skills are synthesized and turned into competencies. Therefore, in order to increase their professional skills, the student must constantly strengthen and develop professional skills, strive to create new skills. Key words: pedagogy, competence, training, information and communication, sociological approach, programming.

В останні роки часто виховується профеесіоналізм та компетентність учителів. Кон- центрація професіоналізму та компетентності у вчителя відзначається як основні риси його педагогічної майстерності та інноваційності вчителя. Ця проблема, яка займає одне з головних місць в освітній політиці, є одним із питань підготовки вчителів та просресійної діяльності вчителя. Виховання цих якостей є одним із перших і головних фракторів забезпечення ефективності, особистісно-орієнтованої та орієнтованої на результат педагогічної діяльності. Професіоналізм та компетентність вчителя робить профресію вчителя більш престижною, цікавішою, змістовнішою та ефективнішою. Не секрет, що низький прооресіоналізм та низький рівень компетентності деяких викладачів відіграють значну роль у занепаді педагогічної професії та репутації вчителів. Профресіоналізм та компетентність учителя повинні допомогти студентам краще вчитися, отримувати глибші та всебічніші знання, навички та звички в навчальному процесі, опановувати моральні цінності, фоормуватися як конкурентоспроможні професіонали, виховуватися як гідні члени суспільства, національні та загальнолюдські, створює сприятливе середовище для засвоєння цінностей. В азербайджанській освіті великий попит на компетентних та професійних учителів, учителів, які опановують нові технології, успішно використовують їх у навчанні, застосовують інновації у своїй діяльності, прив'язані до школи, своєї професії, вважають викладання своїм життєвим кредо, буквально дихають цим. Тому вивчення чієї теми є актуальним. Під час написання статmі були проаналізовані джерела, Інтернет-ресурси та законодавчі документи, написані у відповідній галузі. Вдосконалення професійної підготовки вчителів, їх інтерес до інновацій, постійне підвищення їх професійних та профоесійних знань, умінь та навичок, самоосвіта, самоосвіта та педагогічна творчість $\epsilon$ основою становлення профресійного та компетентного вчителя. Компетентність поєднує в собі важливі сторони особистості. Компетентності формуються на основі вмінь. Багато навичок синтезуються i перетворюються на компетенції. Тому для підвищення своїх професійних навичок студент повинен постійно зміцнювати та розвивати професійні навички, прагнути до створення нових навичок.

Ключові слова: педагогіка, компетентність, навчання, інформація та комунікація, \begin{abstract}
соціологічний підхід, програмування.
\end{abstract}
of Pedagogy of Preschool Education

Azerbaijan State Pedagogical University
Introduction. Improving the professional and professional training of teachers, their interest in innovation, constantly increasing their professional and professional knowledge, skills and habits, self-education, self-education and pedagogical creativity are the basis of his formation as a professional and competent teacher. A teacher can be formed as a professional teacher by not being satisfied with the knowledge he has acquired at school, the methodology he has mastered, and by constantly working on 
himself. Increasing the level of professionalism and competence of a teacher is a process directly related to his pedagogical activity. This is primarily due to the fact that pedagogical activity itself is in constant need of innovation. Pedagogical activity is a work that requires innovation. Its absence monopolizes pedagogical activity, reduces its attractiveness, diversity and slows down the development of students, reduces the effectiveness of teaching.

Methodology. To investigate the current topic, some methods are considered to be appropriate. The main one is the method of observation. In order to study the topic in more detail, the behaviors of the teachers according to the relevant category were observed. In addition, methods of analysis, synthesis, induction, deduction were used.

Theoretical underpinning. The following sources were cited in conducting and writing the research: Sorokina T.M. "Development of the professional competence of the future teacher by means of integrated educational content" [11]; Kodzhaspirova G.M. "Pedagogy" [9]; llyasov. M. I. "Modern problems of teacher professionalism and pedagogical competence" [5]; Alizade A., Alizade H. "Pedagogical psychology" [1]; llyasov M.I. "Teacher's pedagogical skills" [6]; Carnegie D. "The art of making friends and influencing people" [3]; Kazimov N.M. "School pedagogy" [7]; Karimov Y.Sh. "Pedagogical research methods" [8]; Comenius Y.A. "Great didactics" [4]; Mahmut Achel. "Body language of a professional teacher" [2]; Makarenko A.S. "Selected pedagogical works" [10].

Discussion. The teacher's competence is interpreted as the ability of a person to solve many pedagogical problems at different levels. In TM Sorokina's research, the concept of teacher professional competence is interpreted both as a dynamic procedural aspect of vocational training and as a professional change in professional growth characteristics, motivation and activity [11, pp. 110-111].

- Tolerance - in a changing and multicultural society, it is a very important component for a teacher to treat students the same without making any distinctions.

- Being open to questions is a requirement for discussion in class and inspiration for group work. Therefore, the teacher must be open to questions and prepare himself/herself for it. Comprehensive explanation of the question increases the student's interest in the lesson and the stimulus for the emergence of a new question.

- Communication is one of the best teaching methods that clarifies information and ideas in the form of communication. Professional teachers have been using this method for centuries because it is so effective. Of course, the teacher's ability to speak is an important factor.

- Teaching new ones: New teaching skills accompanied by new technologies are important and modern teachers must be able to achieve them.
- Innovative-modern teacher must be innovative and constantly follow the innovations. It also includes new teaching methods, electronic devices, educational programs, new information and communication techniques. A modern teacher should have an "Early Adapter" (an English word meaning "early receiver").

- Passion for new technology - a modern teacher should not only be an innovator, but also love new technology. Must be able to use new tools on the whiteboard or in the presentation, as well as Powerpoint.

- Sociality - the teacher should be more ready to communicate with people, compromise, empathy. The teacher must be able to see the inner world of students, understand it and feel the level of accuracy of what they say.

- Geek (literally translated from English as "pleasure") - the best source for Internet knowledge. The modern teacher must always be full of interest and bring new insights to the students [12].

- Training skills: to organize the learning process, to choose their field of education; to solve problems of training and self-education; to combine knowledge and use its parts; to benefit from educational experience; exceed the responsibility for education.

- Research skills: obtaining and working on information; to refer to and use various sources of evidence; to organize consultations; to imagine different types of material and discuss them in different audiences; use and systematize documents.

- Personal and social competencies: critical approach to the development of society in this and other aspects; to be able to make connections between present and past events; to understand the importance of the political and economic context in educational and professional situations; assess the social situation related to health, needs and the environment; to understand literary works; to hold discussions, to defend their opinions; cope with uncertainty and complexity;

- Communicative skills: listening to the opinions of others, accepting their views; to defend one's point of view; read and write in several languages; to speak in public; to express himself in literary works; read graphs, charts and tables.

- Collaboration skills: decision making; build and maintain relationships; to cope with different opinions and conflicts; negotiate; to collaborate and work in a team.

- Organizational skills: to organize their work; to take responsibility; to master the means of modeling; to connect with groups and societies, to contribute to them; to participate in projects.

- Personal-adaptive skills: use of new information and communication technologies; think of a new solution; show flexibility in change; to be resilient in the face of difficulties; to be ready for self-education and self-organization. 


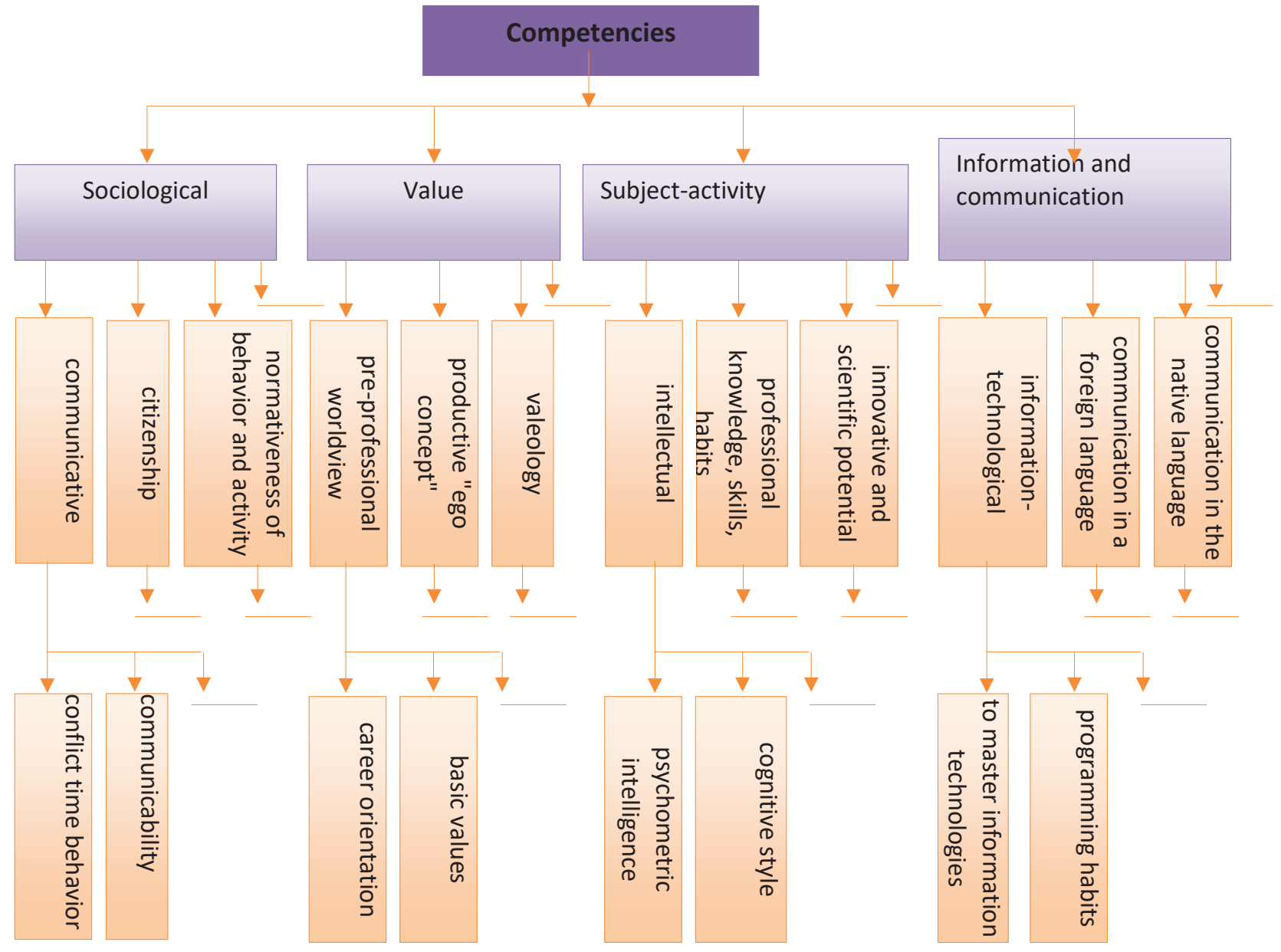

It is clear from the general explanations that today there is no single classification of competence. In the words of GM Khojaspirova, "a teacher must acquire certain pedagogical skills in order to become a competent teacher" [9, p. 428].

Competence combines important aspects of personality. Competences are formed on the basis of skills. Many skills are synthesized and turned into competencies. Therefore, in order to increase their professional skills, the student must constantly strengthen and develop professional skills, strive to create new skills.

In order to acquire professional skills, a teacher must first have the gnostic skills to search, select and apply information that is important for the work process. This is followed by design skills to organize, set goals and plan their activities. Constructive skills that help to choose the means of action, technology are also important for the work of a psychologist. Organizational skills are important in terms of creating, stimulating, and implementing conditions for diagnostics, counseling, and correction. He/she uses his/her evaluation skills to analyze, comprehend and evaluate the user's actions. Uses reflexivity when necessary to analyze one's personality, communication and activities. These skills are interrelated and are important factors in the quality of psychological care.
All this is important in improving the quality of education as a new norm of competence. It is important for every teacher, especially young teachers, to master them. However, as Professor M. Ilyasov writes: "It is difficult to name several specific ways, methods or means to acquire pedagogical competence. That is, the advice "if you do it specifically, you will be competent" is not possible. [5, p. 107].

Scientific novelty of the article. The article puts forward scientifically, pedagogically, methodologically substantiated new ideas on the formation of teachers' sensitive and caring attitude to the schoolchildren. These are the scientific innovations of the article.

Practical significance and application of the article. The article contains new ways of forming sensitive and caring attitudes of teachers to the schoolchildren, areas of practical activity. They can benefit from primary school teachers, researchers in this field and employees of environmental protection agencies.

Result. Globalization and the rapid development of society have brought new shades and innovations to students' worldviews, outlook on life, attitudes towards people and society. They also changed students' attitudes towards school, education, and teachers, and they began to take a more pragmatic approach to events and processes. The time has 
come when a number of teachers (and many of them) are not able to meet the growing demands, desires and aspirations of their students. it is possible by increasing the professionalism and competence of teachers. The school is a school, a center of science, a temple of knowledge with its high-level, competent, professional teachers.

\section{REFERENCES:}

1. Alizade A., Alizade H. Pedagogical psychology. Baku: 2010.

2. Acel M. Body language of a professional teacher. Baku: 2013.

3. Carnegie D. The art of making friends and influencing people. Baku: Law Publishing House, 2015.

4. Comenius Y.A. Great didactics (Scientific editor, preparer and author of the foreword F.Rustamov). Baku, "Science and education", 2012.
5. Ilyasov. M. I. Modern problems of teacher professionalism and pedagogical competence. Baku, "Science and Education", 2018.

6. Ilyasov M.I. Teacher's pedagogical skills. Baku: Science and education, 2013.

7. Kazimov N.M. School pedagogy. Baku: Çaşıŏlu, 2002.

8. Karimov Y.Sh. Pedagogical research methods. Baku: Azerneshr, 2009.

9. Kodzhaspirova G.M. Pedagogy. M .: Gardariki, 2004, 528 p.

10. Makarenko A.S. Selected pedagogical works, Volume II. Baku: 1988.

11. Sorokina T.M. Development of the professional competence of the future teacher by means of integrated educational content. Elementary school, 2004, no. 2, p. 110-114

12. "10 Mind Mapping Strategien für Lehrer", https://www.goconqr.com/de/examtime/blog/10-mindmapping-strategien-fuer-lehrer/ 